\title{
Piotr Dyczek
}

(Warsaw)

\section{TERRA INCOGNITA: RESULTS OF POLISH EXCAVATIONS IN ALBANIA AND MONTENEGRO ${ }^{1}$}

\section{Abstract}

Has been presented new results of polish excavations led by archaeologists from University of Warsaw, in two Illyrian capitals: Rhizon and Scoder.

\section{Key words}

Rhizon, Scoder, roman colony, fortifications, Illyrian palace, ottoman period

1 The project has been financed with resources provided by the National Science Center, Poland, allotted on the basis of decisions: DEC-2015/19/B/HS3/02056 and DEC-2014/14/M/HS3/00741. 
Terra incognita, Ptolemy's term used in his cartographic atlasis no longer adequate in reference to Albania and Montenegro in the $21^{\text {st }}$ century, unless one takes the archaeological perspective, and then it is still justified. Information on the archaeological past of Monenegro is very modest. Most people will have heard about Crvena Stijena, a unique site going back 180,000 years and about Dukla from the $8^{\text {th }}$ century AD. One of the most interesting periods in Montenegro history, the time of Illyrian civilization in this region, is practically unknown, and the same can be said about Albania. Durres/ Epidamnos/Dyrrhachion, Apollonia and Byllis are commonly known ${ }^{2}$, but the ruins that can be seen there reflect the Greek colonies and cities and not the ancient Taulantii and other Illyrian tribes. The store of archaeological knowledge is growing, not the least because of the work done by Polish specialists from the Center for the Research on the Antiquity of Southeastern Europe of the University of Warsaw, who have been digging two ancient Illyrian capitals, Rhizon in Montenegro and Scoder in Albania, for many years now (fig. 1) and who also have at their disposal the great work done by the polymath Włodzimierz Pająkowski from the Adam Mickiewicz University in Poznań, who has also dealt with Illyrian archaeology ${ }^{3}$.

Despite the brevity of our archaeological research so far, the results have demonstrated not only that our understanding of Illyrian culture or to put it more broadly, of Hellenistic culture in the eastern Adriatic, is modest, but that in many instances it does not reflect the reality of the ancient past. In short, the "Illyrian" terra incognita that emerges from the mist of history is a much vaster and varied land than previously assumed.

New questions are being raised as the work proceeds and I would like to turn your attention to some of these now.

One of the most important issues in Illyrian archeology today concerns the origins of Illyrian cities. Many archaeologists, not only Albanian ones, have debated the question ${ }^{4}$. Diodorus ${ }^{5}$ used the term ethne to refer to Illyrian settlement as small tribal centers, using the term polismata, small fortified towns, most likely in a synonymous meaning ${ }^{6}$. Other ancient reports, such as

\footnotetext{
${ }^{2}$ N. Ceka, The Illyrians to the Albanians, Tirana 2005, pp. 271-290.

${ }^{3}$ W. Pająkowski, Ilirowie, Poznań 1981.

${ }^{4}$ Cf. F. Fistani, Vendbanimiifortifikuar Vendbanimiifortifikuarilir i Kratulit, 1, Iliria 1983, pp. 109-117; G. Hoxha, Kalaja e Mosketi, Candavia 1, 2004, pp. 245-250; S. Islami, Qyteti ilir në Zgërdhesh, Iliria 2, pp. 195-213; B. Lahi, Kalaja e Ganjollës, Illiria 1992, nos 1-2, pp. 201-218.

${ }^{5}$ Diod. XVI, 4,7 .

${ }^{6}$ P. Cabanes, Les Illyriens de Bardylis à Genthios (IV'e-II e s. av. J.C.), Paris 1988, p. 214.
} 
Frontinus ${ }^{7}$, use polis, civitas and urbs. Apparently, there was no apt term that could be used to describe the specific urban form and socio-political organization of Illyrian settlement. Therefore, they focused on different aspects, at one times social, at others urban. The excavations at Rhizon ${ }^{8}$ have provided new data on the subject in the form of ancient sources associating Cadmus and Harmonia with this site and the tribal territory of the Enchelai'. They were said to have founded the city and given rise to the Illyrian kingdoms. It would suggest that the Enchelai were the founders of the first Illyrian proto-state ${ }^{10}$ and that models from Greek culture or more strictly speaking models reaching back to Mycenaean culture were at play, providing direct stimuli in this region. It would hardly be surprising in view of the vast region in which this influence was felt ${ }^{11}$. More importantly, however, at the core of this settlement was a developed local culture ready to assume and subsume these new models.

Many elements of the ancient Hellenistic urban architecture have been recorded in excavation at Risan ${ }^{12}$. The lower town (fig. 2) of about 6 ha in area was surrounded by a huge defense wall with towers at the ends of the streets. Channels were cut through the walls to discharge water outside. The fortifications were adapted to the topography. Along the river edge the wall followed a zigzag line, being founded on the rocky ground; along the seaside they ran in a straight line, at the base of the hills and adapted to the ground

\footnotetext{
${ }^{7}$ Stratagèmes III, 6,3

${ }^{8}$ P. Dyczek, Rhizon in der Zeit des Königs Ballaios, Kontaktzone Balkan, Beiträge des internationalen Kolloquiums Die Donau-Balkan-Region als Kontaktzone zwischen Ost-West und Nord-Süd vom 16.-18. Mai 2012 in Frankfurt a. M., Kolloquien zur Vor- und Frügeschichte, 20, 2015, pp. 107-116.

${ }_{9}^{9}$ P. Lisičar, Legenda o Kadmu, Živa antika 3, 1953, pp. 245-260; W. Pająkowski, Ilirowie, pp. 19-20; M. Šašel Kos, Cadmus and Harmonia in Illyria, Arheološki vestnik 44, 1993, pp. 113-136, eadem, Mythological stories concerning Illyria ant its name, [in:] P. Cabanes, J-L Lamboley (eds.), L'Illyria méridionale at l'Épire dans l'Antiquité, Paris 2004, pp. 500-501.

${ }^{10}$ W. Pająkowski, Ilirowie, pp. 16-17, 87-90; N. Prodeva, Enchéléens-Dassarétes-Illyriens. Sources littéraires, épigraphique et archéologiques. L’Illyrie méridionale et l'Épire dans l'Antiquité. Actes du $2^{\text {e }}$ Colloque International de Clermont-Ferrand, 25-27 octobre 1990, Paris 1993, pp. 195-199; S. Shpuza, Iron age fortifications and the origin of the city in the territory of Scoder, Novensia 25, 2014, pp. 105-126.

${ }^{11}$ G. Hoxha, Gjurmë të periudhës së bronzit të hershëm në kalanë e Shkodrës, Iliria 1, 1987, pp. 71-81.

${ }^{12}$ P. Dyczek, Rhizon, 2004-2007. Preliminary Report on the Excavations of the Center for Research on the Antiquity of Southeastern Europe, Warsaw University, Archeologia 58, 2007(2008), pp. 121-139, pls. XVII-XVIII, idem, Rhizon, 2008-2012. Preliminary Report on the Excavations of the Center for Research on the Antiquity of Southeastern Europe, University of Warsaw, Archeologia 62-63, 2011-1012, 2014, pp. 91-109.
} 
relief. The polygonal walls, referred to as „Cyclopean”, (fig. 3) were made of large rectangular stone blocks in the emplecton masonry bond. They were about $2.60 \mathrm{~m}$ thick and stood about $10 \mathrm{~m}$ high. The square and rectangular inner towers protected the four main city gates. The fortifications, like many other Cyclopean walls from Illyria, were dated per analogiam. The Risan walls could be dated by Hellenistic potsherds from the end of the $4^{\text {th }}$ and early $3^{\text {rd }}$ century BC found in the foundation trenches and coin finds in the 2016 season should make direct dating possible as well.

The monumental nature of the defense walls was reflected in much later sources as well. They were described as moenia Aecia in a mid- $2^{\text {nd }}$ century $\mathrm{AD}$ dedicatory inscription to the local Illyrian divinity Medaurus made by a legionary from Rhizon in the II Augusta legion stationed at Lambaesis in North Africa ${ }^{13}$. This appellation referred not only to the Trojan tradition, but also to the Mycenaean and Greek origins of the town. It serves as a unique example for all of Illyria.

Earlier fortifications were discovered on the hill above the city, where also remains of the earliest Bronze Age architecture have been located. A small oval area was surrounded bya wall of large broken stones (fig. 4). This structure was incorporated into the later architecture perhaps intentionally, but shortly thereafter a Cyclopean wallwas constructed at the top of the hill ${ }^{14}$, possibly to support a large crepidoma under a tentative cultic structure. The Risan acropolis is merely $1000 \mathrm{~m}^{2}$ in size and incorporates no larger buildings, but it was well fortified and must have played an important role for the local inhabitants, who connected the lower city with it by a fortified road.

The lower town was divided into districts. The main streets marked out a grid for the urban space, but it was not an orthogonal plan. There were many cul-de-sacs and streets that became narrow and widened again. The architecture of the houses in generally Hellenistic in nature, but always a variation on the standard model in use. Courtyards are present as are

\footnotetext{
${ }^{13}$ M. Garašanian, Moenia Aecia Starinar 17, 1966, pp. 27-36; P. Dyczek, Lar populi sancte Medaure... (CIL III, 2581 = ILS 4881), Anodos. Studies of the Ancient World 6-6 (2006-2007) 2008, pp. 155-163; idem, J. Kolendo, A. Łajtar, T. Płociennik, K. Rzepkowski, Iliryjski bóg Medurus i mury Risinium w świetle inskrypcji metrycznej z Lambaesis (CIL VIII 2581; F. Buecheler, Carmina Latina epigraphica 1527), Novensia 21, 2010 (2012), pp. 79-133; P. Dyczek, J. Kolendo, A. Łajtar, T. Płociennik, K. Rzepkowski, Une inscription métrique de Lambaesis (CIL, VIII, 2581; F. Buechler, Carmina Latina epigraphica, 1527) et la statue du dieu illyrien Médaure, Antiquités africaines, 50, 2014, pp. 73-84.

${ }^{14}$ P. Mijović, M. Kovačević, Gradovi i utverđenja u Crnoj Gori, Ulcinj 1975, p. 25, fig. 17.
} 
narrow corridors, rooms have different functions that may be identified occasionally based on the finds: kitchens, women's quarters, storerooms, etc.

Each of the six insulae that the team has explored in part is of a different character. Storerooms filled with mainly imported amphorae were found nearer to the river estuary. The shops were located there as well. Interestingly, this part of the town retained its character through the Roman age as indicated by the excavated remains of round granaries, large pithoi and grain-drying installations with hypocaust systems. The further from the sea and closer to the acropolis, houses become more solid in construction and larger in size. This appears to be a workshop quarter that apparently specialized in furniture-making for a luxury market. The craft is suggested by huge quantities of nails of all shapes and sizes, including upholstery tacks and thick layers of burnt wood which could not be associated with house construction. Copper ore in lumps and hematite were also found. A considerable number of net-sinkers, including ones made of lead, as well as fish bones and mollusk shells, are indicative of a prosperous fishing industry. Loom weights also found extensively suggest textiles being woven here for export. Purple dyes may have also been produced considering the shell evidence found. Large quantities of imported Hellenistic tableware of all types, including Gnathia, testify to the affluence and tastes of the town's inhabitants.

Despite the limited size of the excavation compared to the overall size of the town, three separate bathrooms with terracotta baths have been unearthed, including a bathtub for children. The best preserved of the bathrooms contained an early Hellenistic mosaic made of small limestone pebbles and red potsherds ${ }^{15}$. These bathrooms are the earliest installations of the kind anywhere in the Balkans and are definitely a mark of luxury that is seldom found, especially in a small town like Rhizon. The people who had them built for themselves were obviously wealthy and cultured.

In considering the urban structure of Rhizon the excavators had to come to grips with the question of the ruling authority and its architectural emanation. Ancient sources repeatedly mention Illyrian kings and in the $3^{\text {rd }}$ century BC Rhizon was undoubtedly one of the state capitals, so where was the residence of the rulers located? Without going into the details of our reasoning, we chose for excavation in the past two seasons the highest lying

${ }^{15}$ P. Dyczek, Rhizon, 2001-2003. Preliminary Report on the Excavations of the Center for Archaeological Research - Novae, Warsaw University, Archeologia LV 2004 (2005), pp. 101-118. 
parts of the town, close to the river and a secret postern in the town walls. Two palatial complexes were discovered in effect, the first from about $260 \mathrm{BC}$, the second about a quarter of a century later in time.

Few Hellenistic palatial complexes ${ }^{16}$ (fig. 5) have been studied to date and they all belonged to the known great dynasties. Singular examples of smaller palaces like the one from Rhizon existed, but not from anywhere in Illyria. In terms of the functioning of royal authority in Illyria, the discovery of a palatial complex in Rhizon has added immensely to our knowledge, especially as the buildings appear to have belonged to at least two different kings. The older complex included a megaron-type hall with a central hearth (fig. 6). A foundation deposit in the form of a hoard of 30 coins was found under it.Marble columns stood on either side of the hearth.

The base of one of them was found in the rubble layer resulting from the destruction of this complex. The shaft was smooth from the hearth and fluted on the room-side. Wine amphorae of imported origin stood alongside one wall of the megaron. The fill of the hall included sherds of luxury tableware and other small objects indicating the special function of this interior. Amphora stores were found next to the megaron and in front of the hall a neatly paved square and section of a road. The pavement appears to have been designed with a pattern in mind, some of the stones forming a herringbone ornament. A street paved with flat stone slabs ran between the megaron and the storerooms, leading most probably toward a ceremonial gate from which started the road onto the acropolis. The building burned down in a violent conflagration caused by a raid on the settlement. The rubble yielded lead sling ammunition, intact and flattened by having hit their target in combat, demonstrating the violence of the destruction.

The area was rebuilt after the event. The rubble was leveled, the storerooms reconstructed. The old megaron was turned into a kitchen and/or banquet hall attached to the new palace, which was built in part in the old courtyard. Part of the courtyard now served as a roadleading along the new palace facade. The younger palace was raised of neatly dressed ashlar blocks of limestone joined by the Greek technique of anathyrosis. The architecture was indeed focused on aesthetics with added molding on the corners of the ashlar blocks to give a heightened impression of slenderness of the structure as a whole. A pavement ran around the building, serving as a stylobate for the

${ }^{16}$ I. Nielsen, Hellenistic Palaces, Studies In Hellenistic Civilisation, eds. P. Bilde, T. EngberPedersen, L. Hannelstad, J. Zahle, V, 1999, p. 11. 
facade. The smooth-shafted columns which stood there were engaged, projecting three-fourths from the wall. The incomplete dimensions of the building as it stands today are $15 \mathrm{~m}$ by $5 \mathrm{~m}$. Two large door knockers were discovered in the last season and two others in the season before that (fig. 7). During one of the renovations, possibly after quake-related destruction, one of the entrances was framed with a fine stucco frame including engaged columns modeled in the plaster.

Excavation by the Center in the other capital of Illyria, Scoder ${ }^{17}$, open the way to interesting considerations in reference to the above (fig. 8). Hellenistic urban complexes have yet to be found but the non-invasive prospection conducted until now, among others by G. von Bülow, then with the RGK in Frankfurt, shows that the Illyrian town did not extend beyond the hill. Cyclopean walls divided it into at least two districts serving different functions. The architecture, which followed the topography, formed insulae of sorts but not in a Hippodamian grid. The rocky ground was leveled only where necessary for structural reasons and partly to facilitate communication between areas but without making the street surfaces ideally smooth. Parts of the town were left untouched and cisterns, which were used for a very long time, were made in natural hollows furnished with only the essential stone masonry to make them workable.

The two sites, Rhizon and Scoder, which are complementary to an extent, give a broader and fuller picture of Illyrian settlement and its transformation from Hellenistic to Roman. These traditions were strongly entrenched, enough to leave their mark also on the later Venetian and Ottoman architecture. At Risan later destruction has removed most of the remains younger than the $2^{\text {nd }}$ century $\mathrm{BC}$, but at Scoder the late antique layers and especially the medieval stratum reaching $7 \mathrm{~m}$ in thickness, predominate.

One of the most interesting discoveries was made during an investigation of a cistern constructed in Venetian times and rebuilt by the Turks. Two inscriptions, one whole and the other fragmentary, were immured into the central pillar supporting the roof of the cistern. Three inscriptions were preserved on one of these two blocks ${ }^{18}$ (fig. 9). The Latin text on the front

${ }^{17}$ P. Dyczek, S. Shpuza, Three years of Albanian-Polish excavations in Shkodra, [in:] L. Përzhita, I. Gjipali, G. Hoxha, B. Muka (eds.), Proceedings of the International Congress of Albanian Archaeological Studies. 65 ${ }^{\text {th }}$ Anniversary of Albanian Archaeology (21-22 November, Tirana 2013), Botimet Albanologike, Tiranë 2014, pp. 387-398.

${ }^{18}$ A. Łajtar, J. Żelazowski, Le nuove iscrizioni provenienti da Scodra (Albania) e il nuovo v(ir) e(gregius) ducenarius ${ }^{*}$, ZPE 192, 2014, pp. 273-283; A. Łajtar, S. Shpuza, J. Żelazowski, Nowe inskrypcje z antycznej Szkodry (Albania) znalezione podczas polsko-albańskich badań archeolo- 
brings new data on the military administration and the functioning of the general staff. It concerns a cornicularius of a primus pilus working on the general staff. At the end of the text Scoder is mentioned per se as a Roman colony. The paleography of the text should help to establish the date when Scoder was a Roman colony, something that had not been clear so far, but which is important for knowing when the Romans occupied the region. Fragments concerning the army confirm the hypothesis, theoretical so far, that the Roman army was stationed at Scoder. The scope of research will now include determining the location of the Roman camp and the nature of the troops stationed in it. The lateral sides of the stone base contain two later texts, one in Greek and the other in Latin. The Greek is a text of funerary nature, dating from Christian times: Dynamis, let you live eternally (fig. 10). The Latin is a fragmentarily preserved, but exquisitely decorated tomb marker with the beginning of a funerary inscription from the $2^{\text {nd }}$ century AD.

Investigations in the lower town have brought new information on its development at the turn of the $1^{\text {st }}$ and in the $2^{\text {nd }}$ century $\mathrm{AD}$. This period in Scoder has not seen extensive study yet. A section of a large Roman house with a hypocaust system has been uncovered. It was richly ornamented with exquisite stuccoes on the walls, featuring a variety of motifs, and slabs of colored stone on the floor and walls. There is no doubt that Scoder in the Roman period was a flourishing and prosperous town.

In late Roman times Scoder was the capital of the Praevalis province. The wall surrounding the lower town dates to this period. It had two phases, the first from the turn of the $3^{\text {rd }}$ century, rebuilt about 340 when semicircular towers were added. The chronology has been established by radiocarbon dating of the remains. The date may be linked to the military activities of Constans I in Illyria.

One of the mysteries of Scoder was a bulwark below the north wall of the fortifications (fig. 11). It was a wall of roughly dressed ashlars set in the emplecton masonry technique. Researchers either took them for the remains of a Cyclopean wall or for a medieval structure. The present investigations have identified the wall as a defensive structure raised by the Venetians during the Turkish siege of 1478/1479. The Turks destroyed a section of the walls The written sources had suggested that some of the walls were rebuilt

gicznych, Novensia 25, 2014, pp. 127-143; P. Dyczek, S. Shpuza, Tre vjet gërmime shqiptar o-polake në Shkodër, Iliria 38, 2015, pp. 9-22, iidem, Shkdër. Gërmimet arkeologjike të viteve 2013-2014, Iliria 38, 2015, pp. 279-292. 
and the hill was additionally fortified with timber-and-earth fortifications. It is evident from the recent research that additional stone fortifications were constructed around the city, but only on the side from which the Venetians expected artillery fire. This hurriedly built wall was built in the simplest, although not necessarily least laborious technique, imitating Cyclopean masonry and leading to the later scientific misunderstanding. The Turks quickly learned the effectiveness of this additional line of defenses, having centered their artillery fore on this outer curtain. The minute Scoder fell, they started to adapt the Venetian fortifications to their own defensive purposes.

Three other interesting discoveries concern the $17^{\text {th }}$ and $8^{\text {th }}$ centuries. A set of almost 30 glass aryballoi were found in the ruins of one of the Turkish houses. Some were made of dark green glass, others of colored glass, thus imitating the more expensive vessels cut from colored stone. Even so, the glass vessels were hardly cheap. The house appears to have been a Turkish drugstore.

Another hoard, found this time in a water sewer which is always interesting to the archaeologist, contained a small bag of silver coins struck in Dubrovnik in the early $17^{\text {th }}$ century as well as a series of majolica vessels covered with a colored glaze and even some imported Chinese porcelain. An apothecary's shop in the lower town yielded the remains of scales, vessels and a well preserved small tin pyxis (fig.12). The inscription on its cover identifies its content as theriaca, an antidote known to English apothecaries as Venice treacle.

This brief review of the recent excavation results from Rhizon and Scoder demonstrates the wealth of data still concealed in the Illyrian "terra incognita". New findings on the architecture, chronology and material as well as spiritual culture coming from the present investigations show us a different Illyria than the one existing in the scientific mind so far. The discoveries have posed new research questions, but they are all embraced in one overriding issue: the identity of Illyrian culture, its impact on other cultures of the Hellenistic period and the autochthonous as well as foreign sources of inspiration that shaped it. 
STUDIA EUROPAEA GNESNENSIA 16/2017 · ROME AND THE PROVINCES

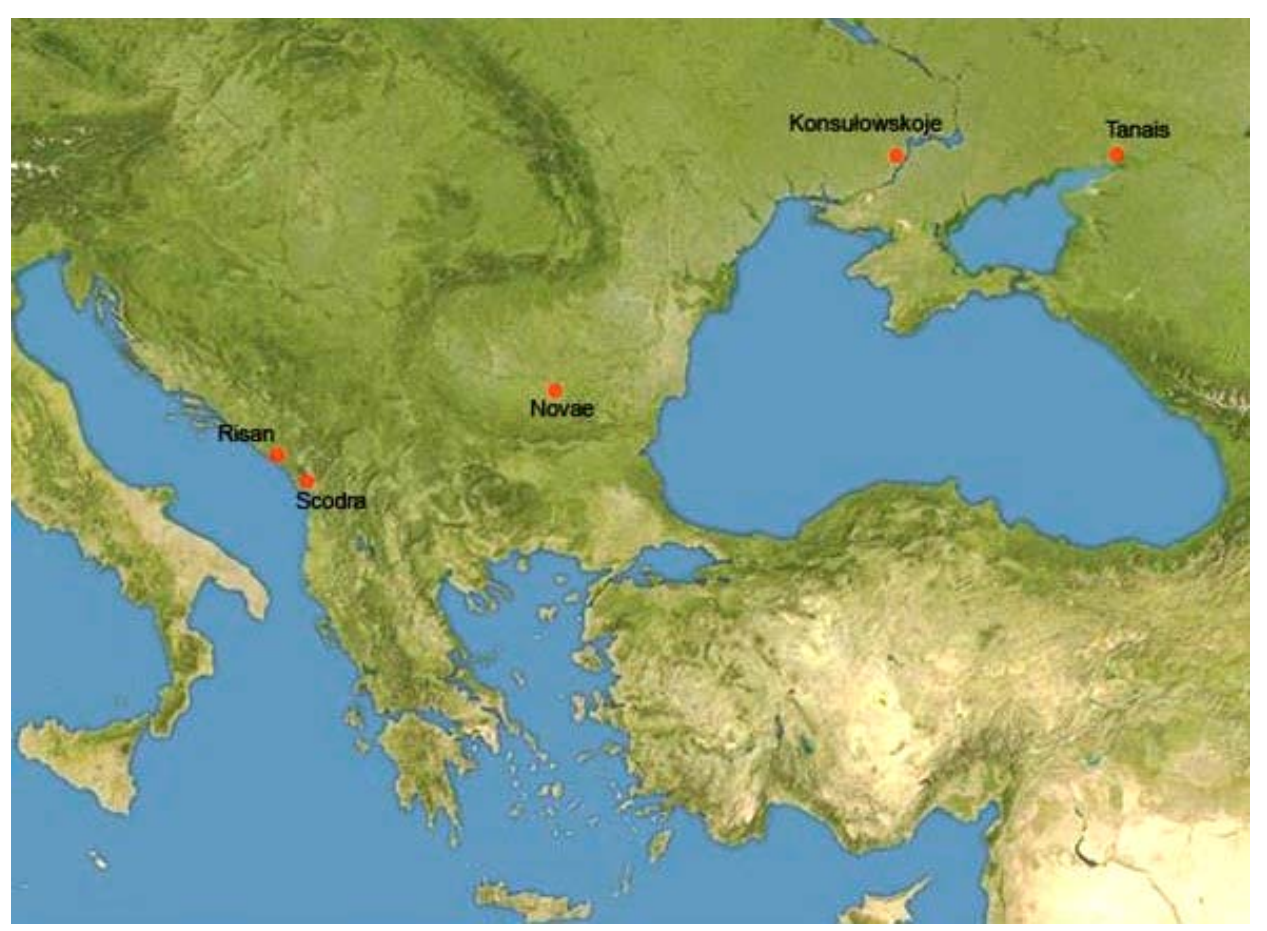

Fig. 1. Localisation of Rhizon and Scoder, A. Momot 
PIOTR DYCZEK, TERRA INCOGNITA: RESULTS OF POLISH EXCAVATIONS IN ALBANIA AND MONTENEGRO

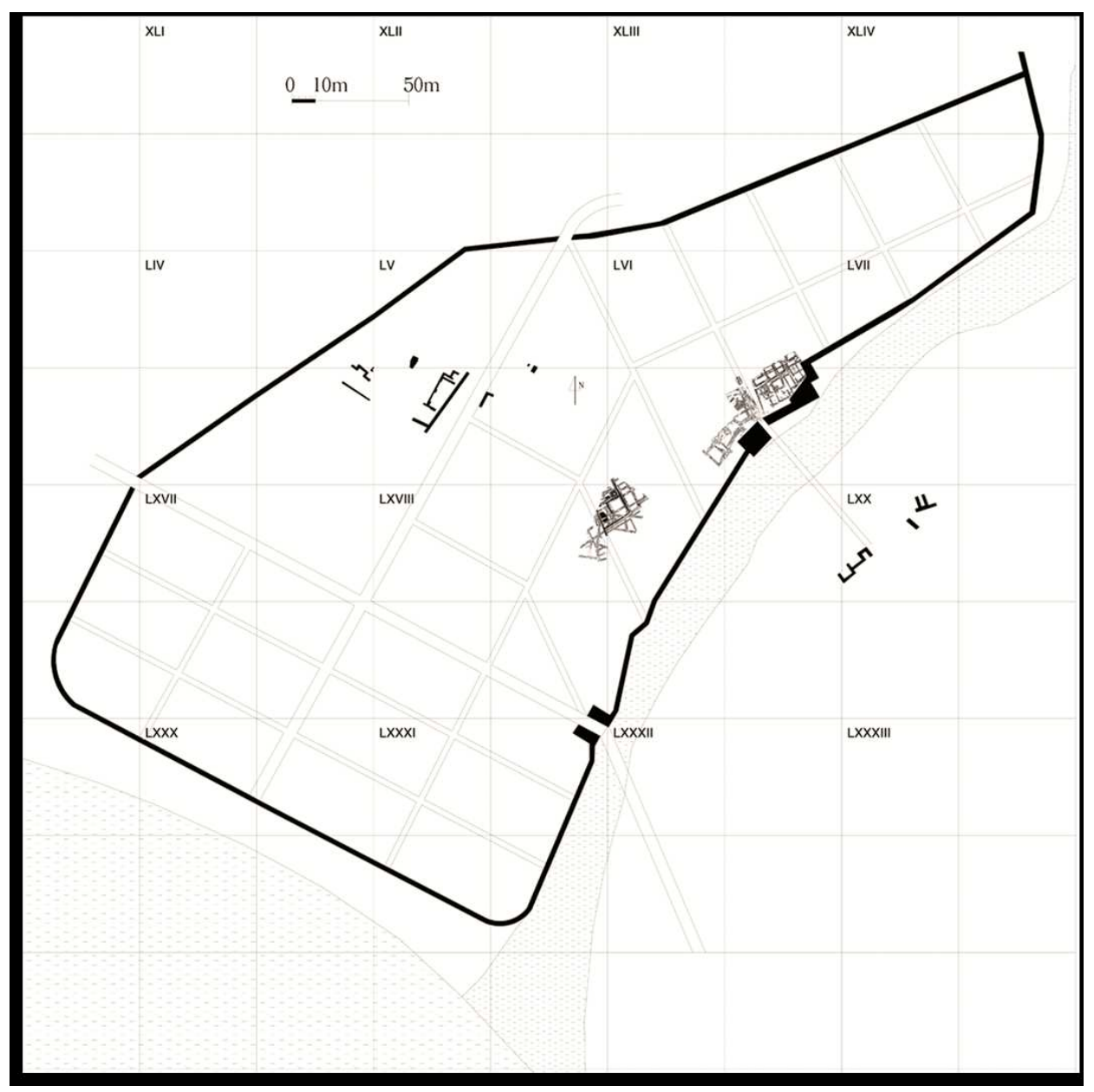

Fig. 2. Plan of ancient Rhizon, by P. Dyczek, T. Słowik 


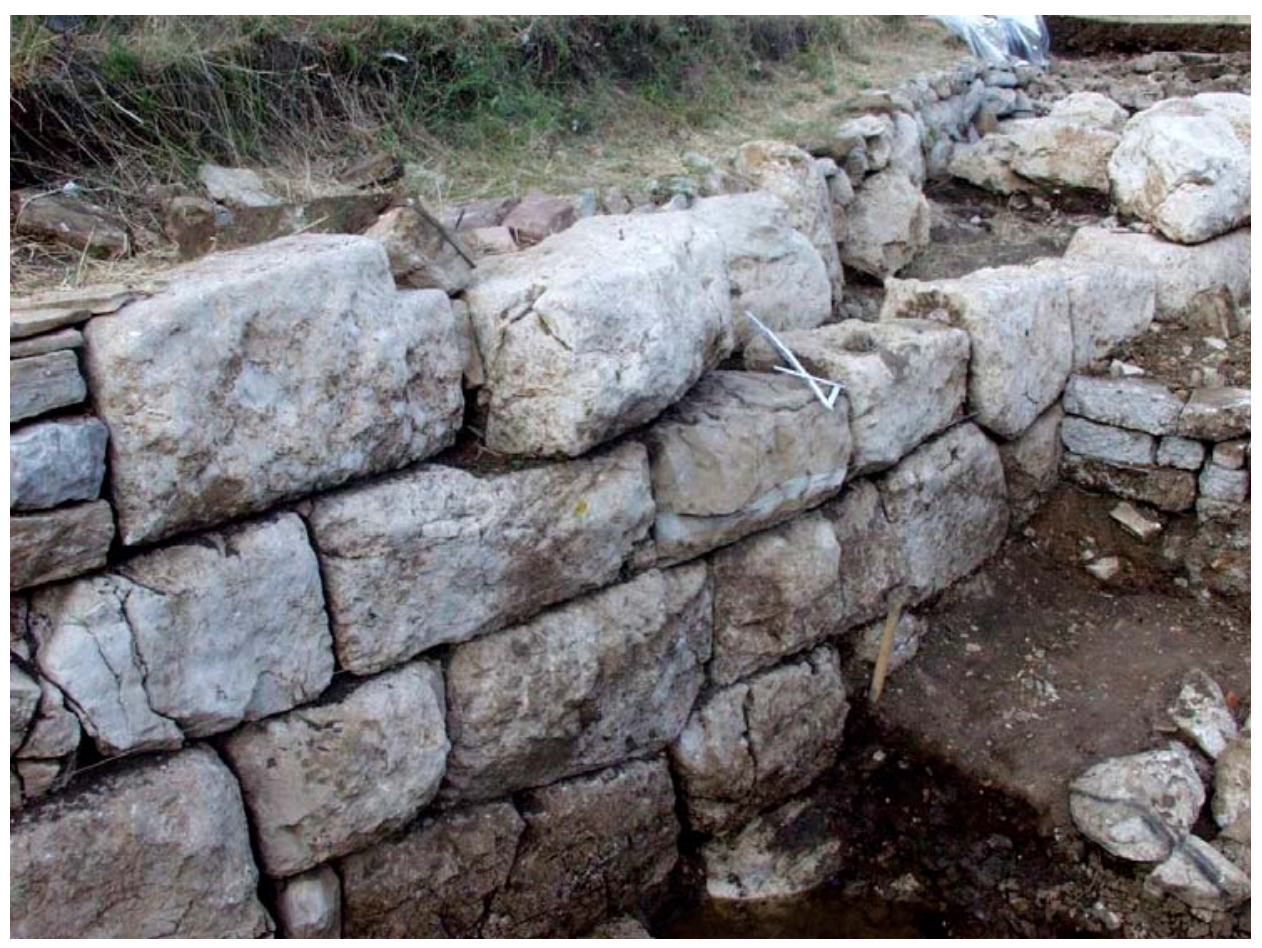

Fig. 3. Cyclopean wall of Rhizon, photo P. Dyczek

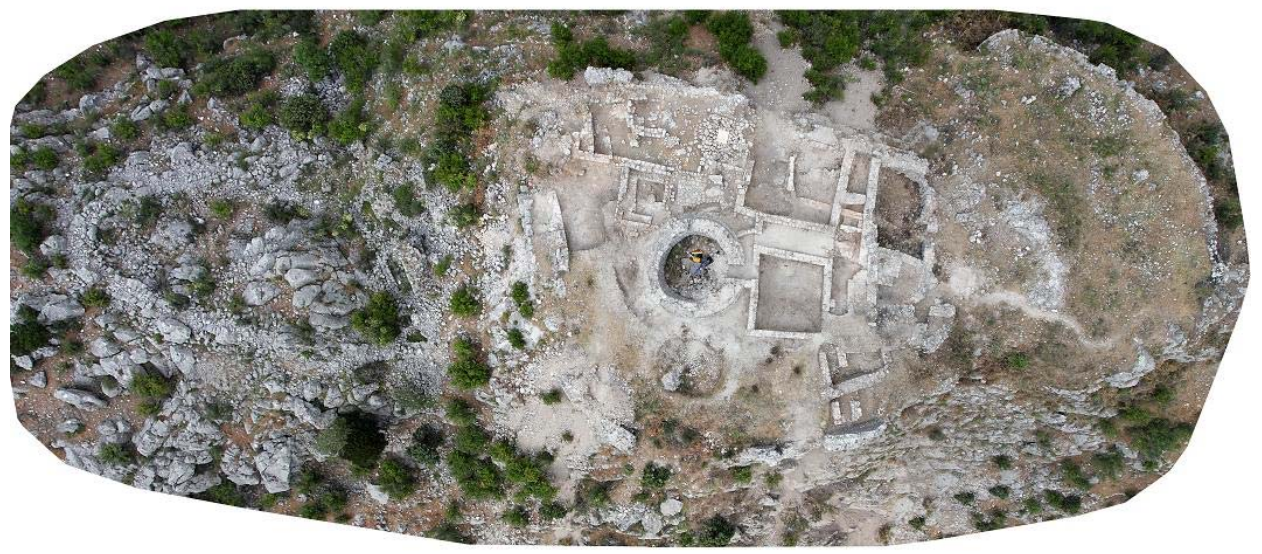

Fig. 4. Aerial view of Gradine - acropolis of Rhizon, S. Rzeźnik 


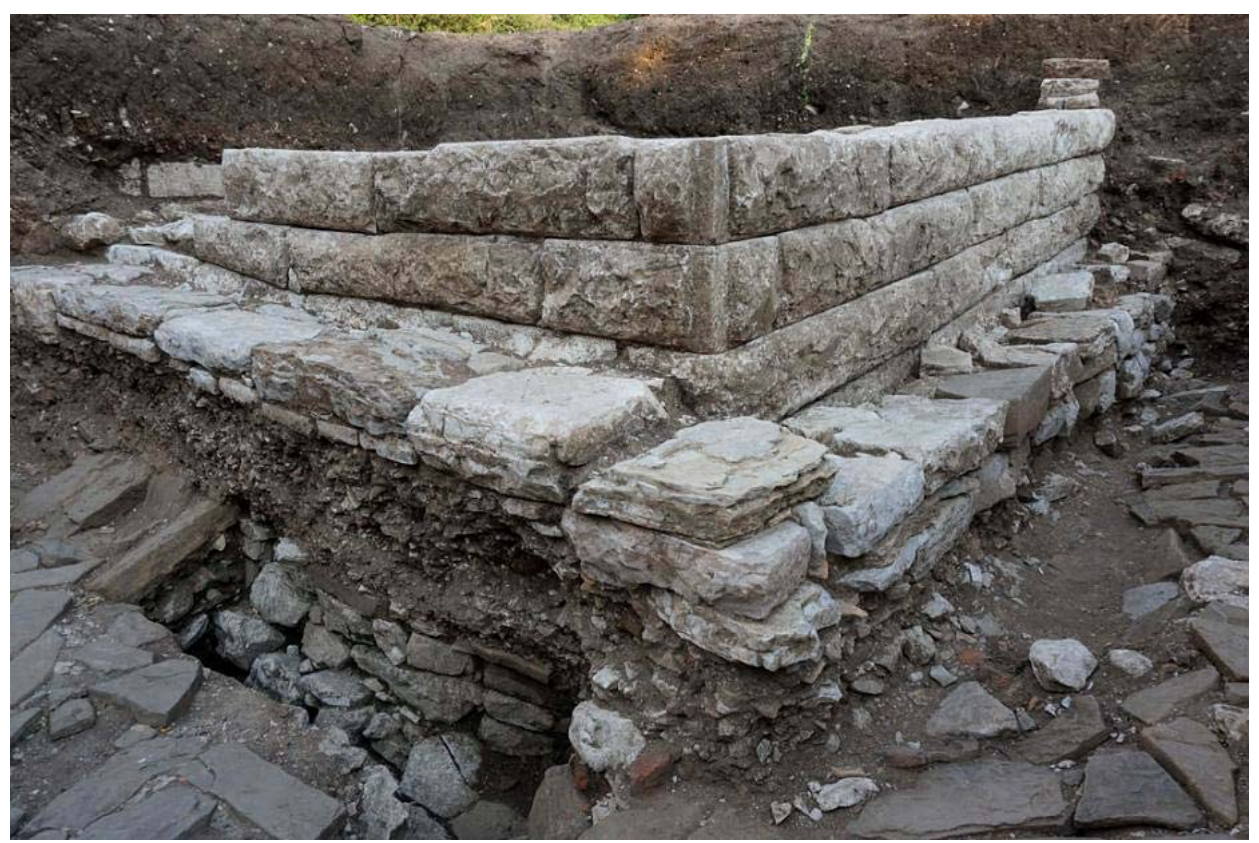

Fig. 5. Walls of representation building in place complex in Rhizon, photo P. Dyczek

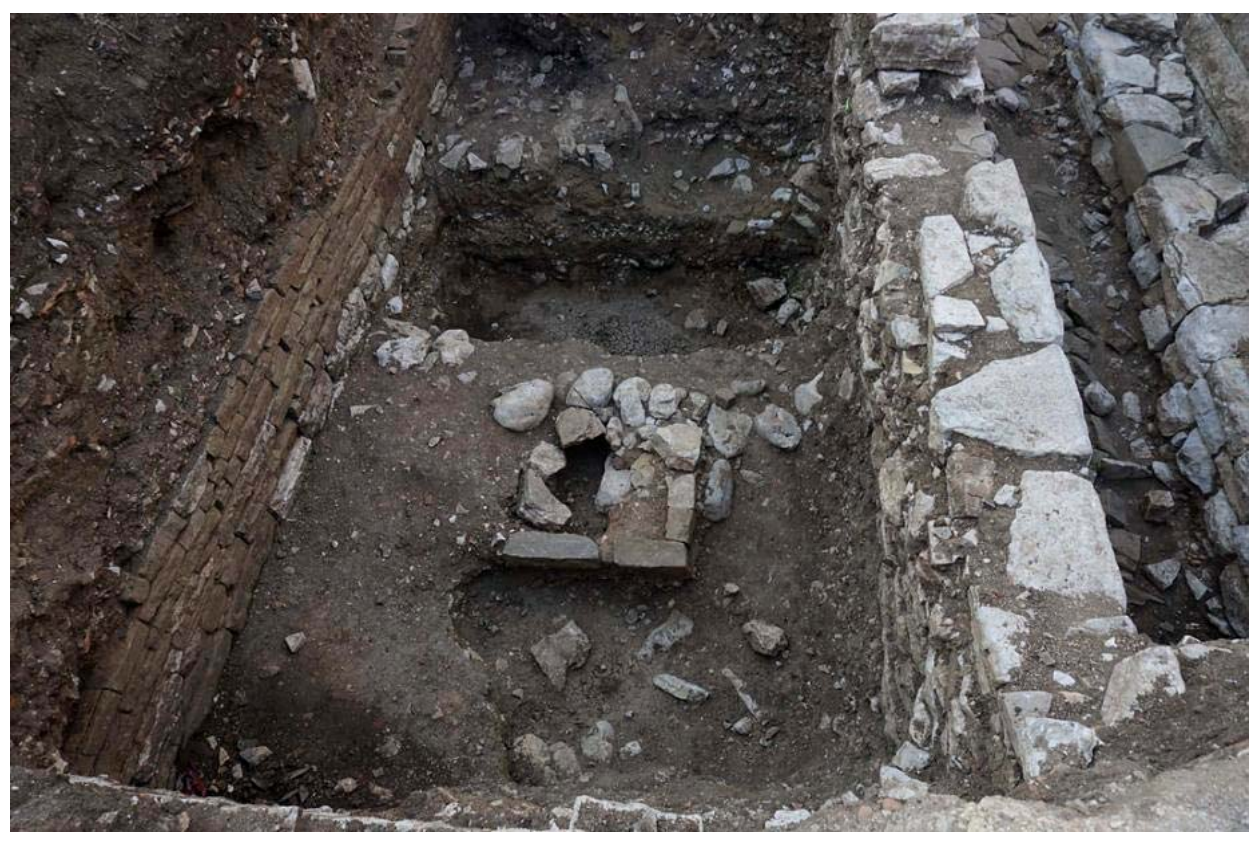

Fig. 6. So called "megaron" from Rhizon, photo P. Dyczek 


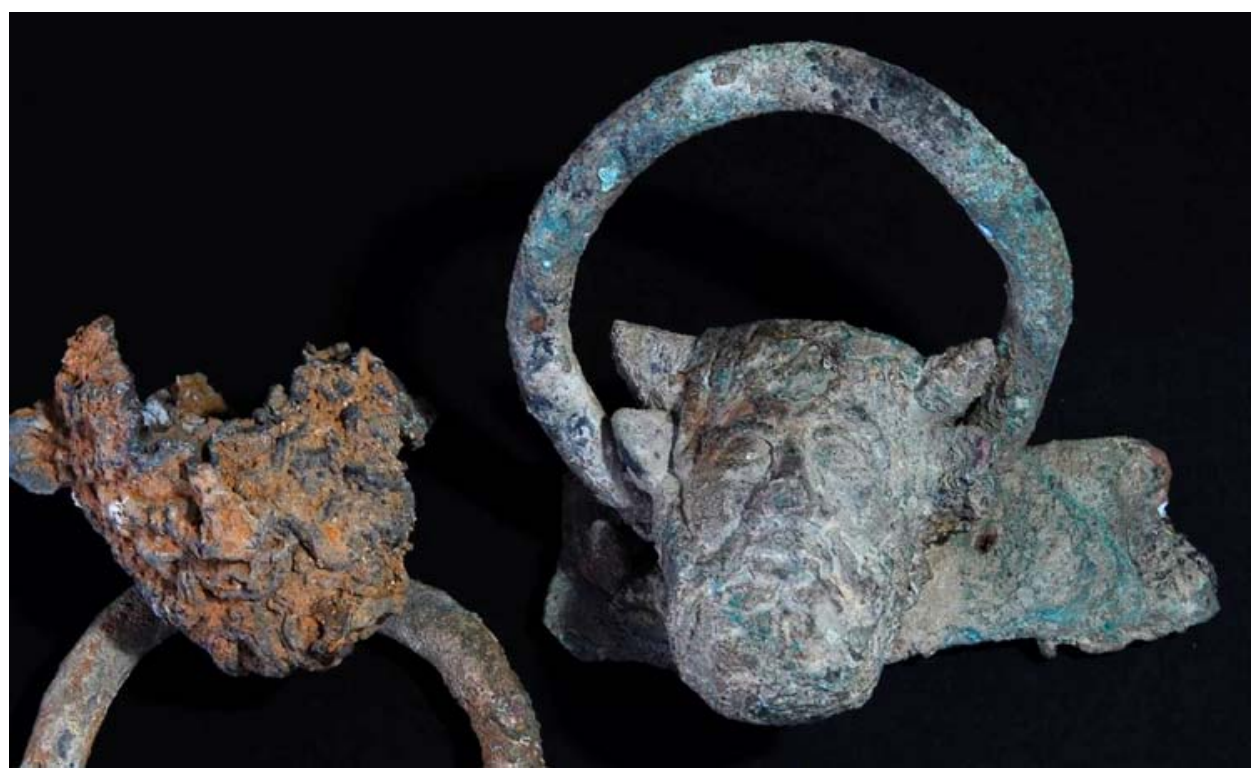

Fig. 7. Two large palace's door knockers from Rhizon, photo J. Recław

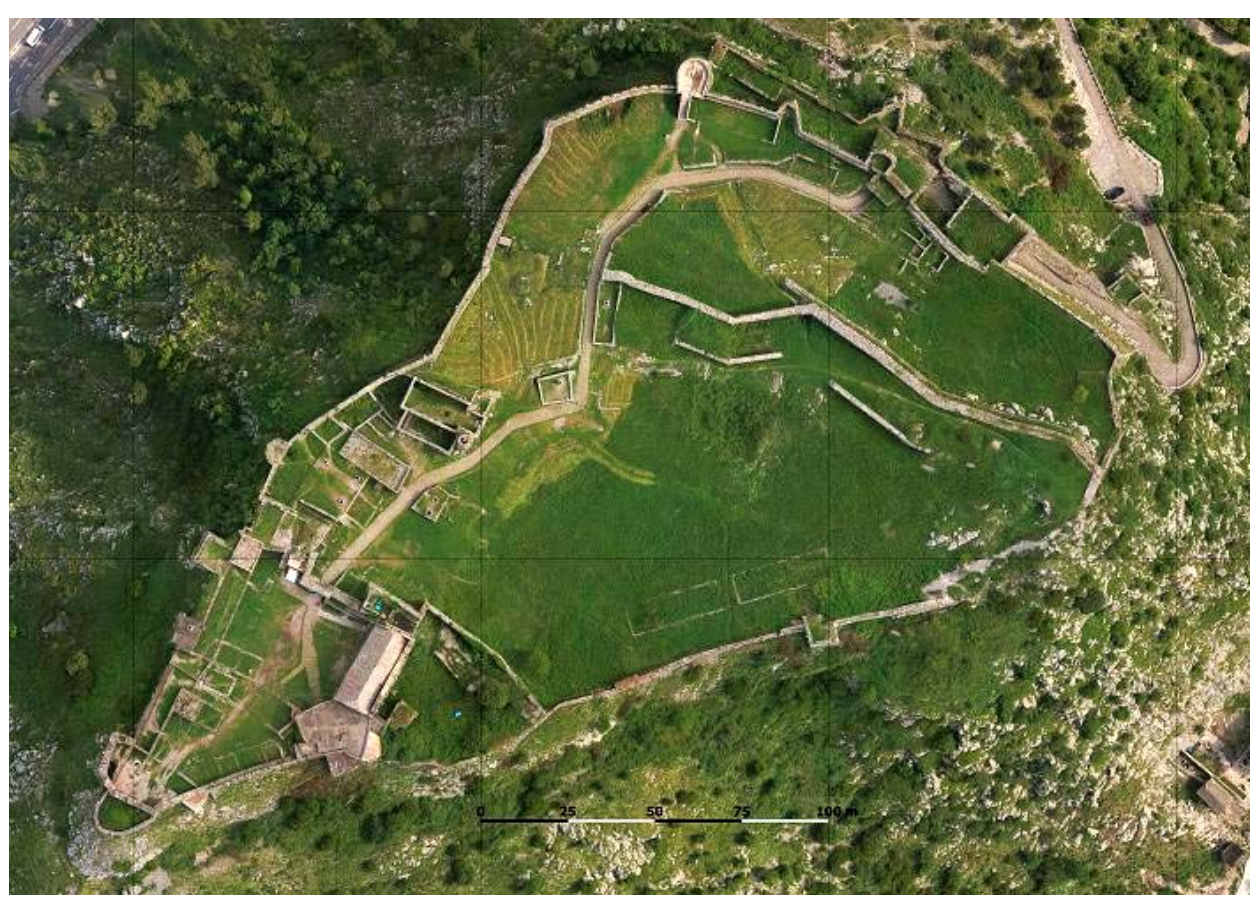

Fig. 8. Aerial view of fortress in Scoder, photo M. Pisz 


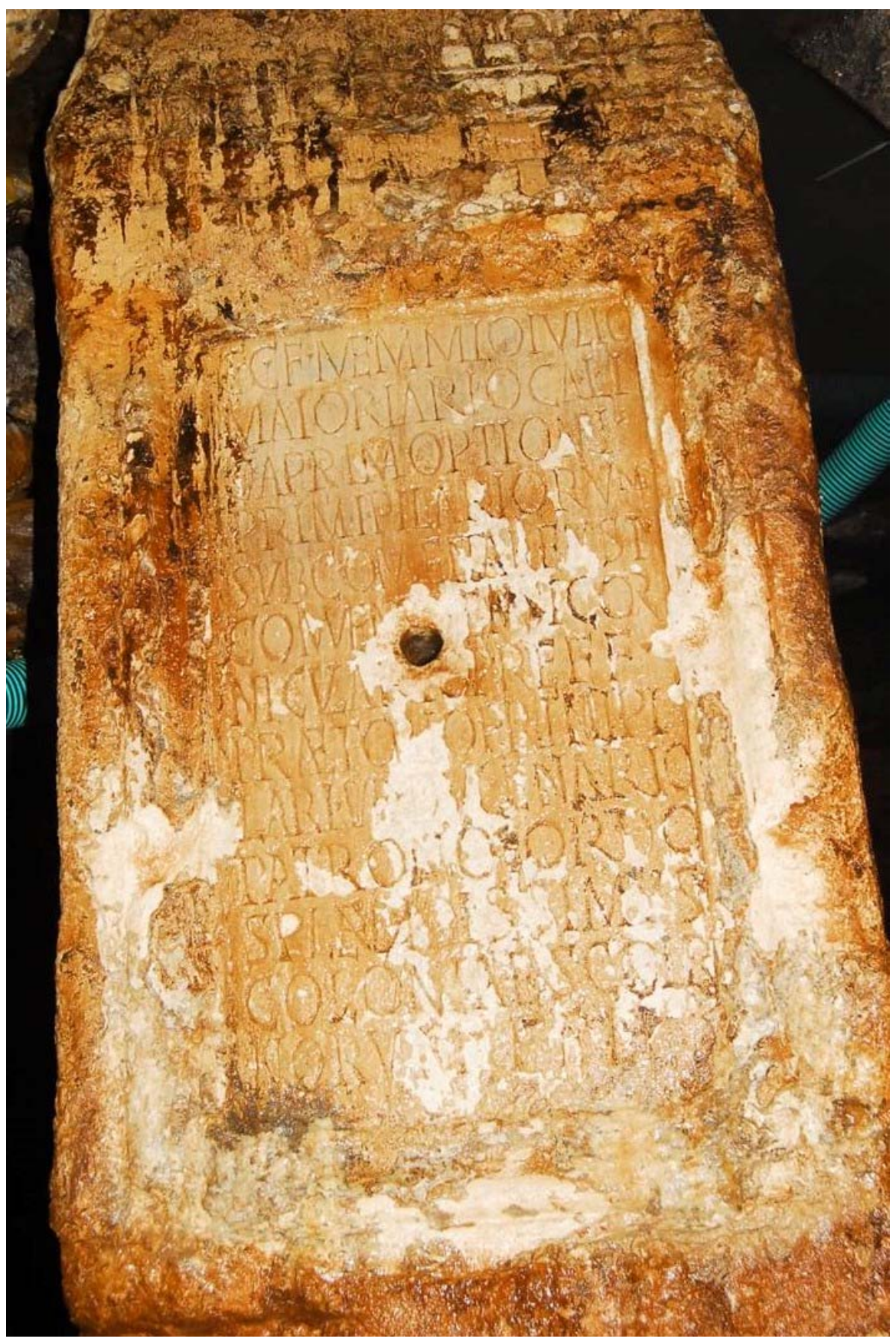

Fig. 9. Roman inscription from cistern - Scoder, photo J. Recław 


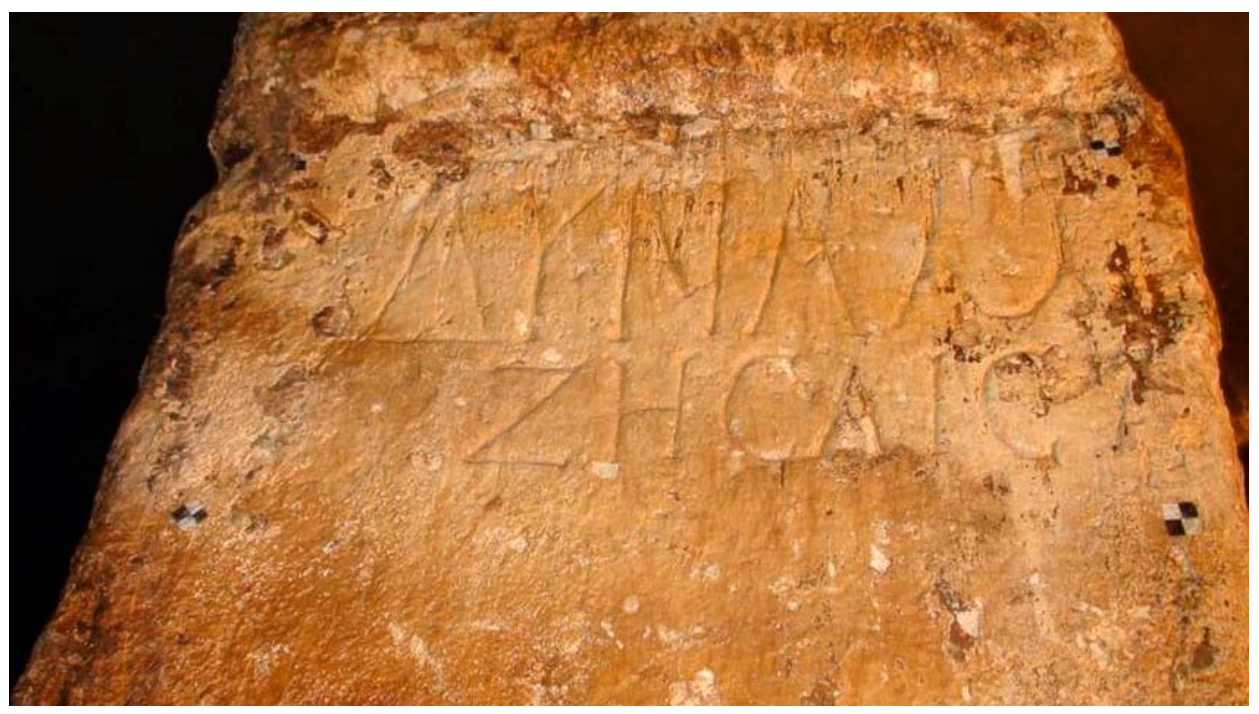

Fig. 10. Greek inscription from cistern - Scoder, photo J. Recław

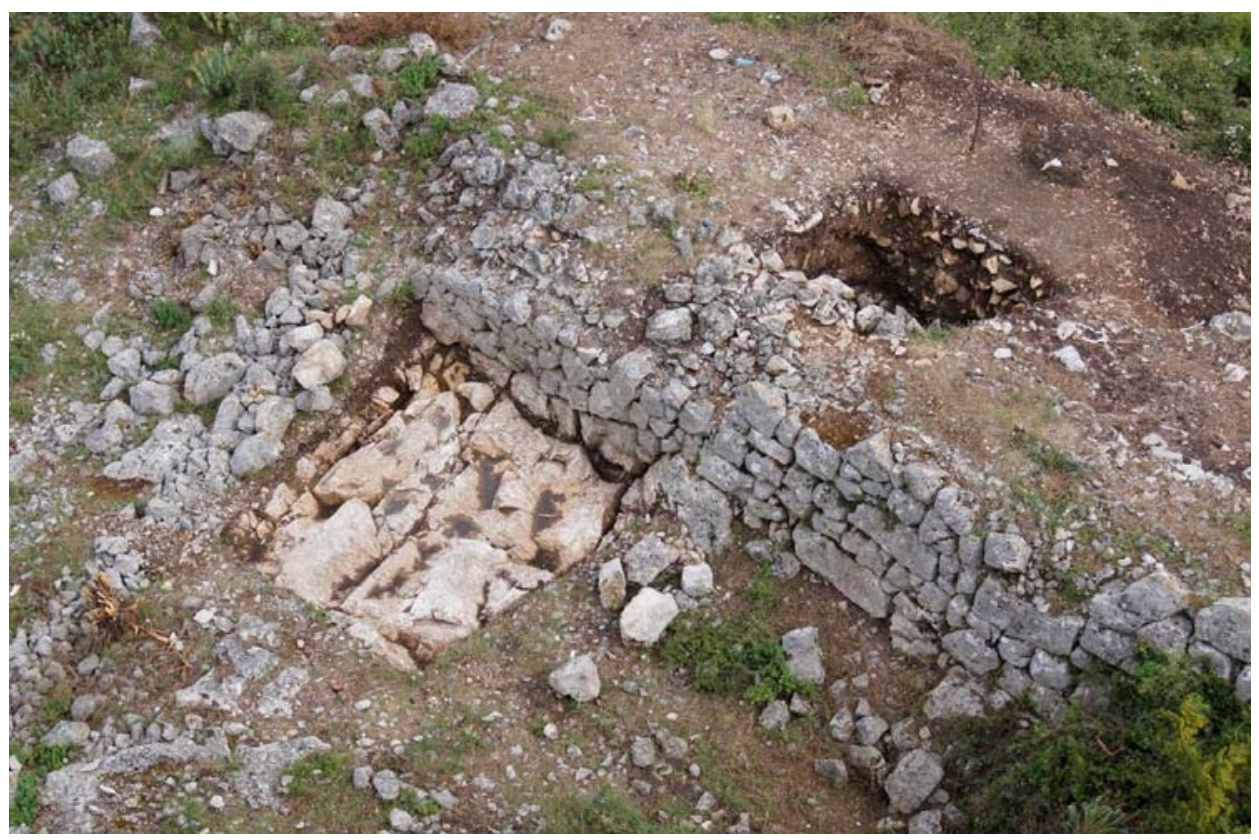

Fig. 11. Medieval wall - fortress of Scoder, photo P. Dyczek 


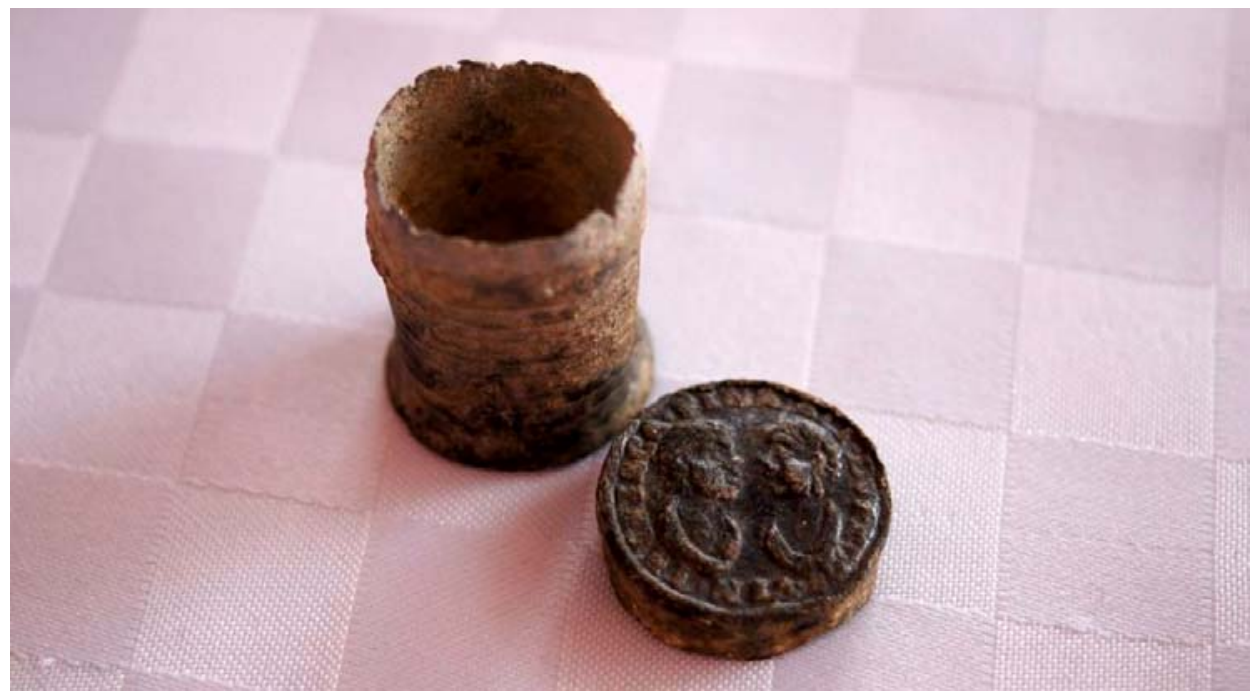

Fig. 12. Pyxis for thyriacum - Scoder, photo S. Shpuza

\section{Summary}

One of the most important issues in Illyrian archeology today concerns the origins of Illyrian cities. The excavations at Rhizon have provided new data on the subject where many elements of the ancient urban architecture have been recorded. First, the monumental defense walls so called - Cyclopean wall. The lower town was divided into districts, but it was not an orthogonal plan. The architecture of the houses in generally Hellenistic in nature, but always a variation on the standard model in use each of the six insulae. Despite the limited size of the excavation compared to the overall size of the town, three separate bathrooms with terracotta baths have been unearthed, including a bathtub for children. In considering the urban structure of Rhizon the archaeologists had to come to grips with the question of the ruling authority and its architectural emanation. In terms of the functioning of royal authority in Illyria, the discovery of a palatial complex in Rhizon has added immensely to our knowledge. The older complex, included a megaron-type hall with a central hearth, storerooms and large courtyard The area was rebuilt after the event. The rubble was leveled, the storerooms reconstructed. The old megaron was turned into a kitchen and/or banquet hall attached to the new palace, which was built in part in the old courtyard. Part of the courtyard now served as a roadleading along the new palace facade. The younger palace was raised of neatly dressed ashlar blocks of limestone joined by the Greek technique of anathyrosis. 
Excavation in the other capital of Illyria, Scoder, open the way to interesting considerations in reference to the above. One of the most interesting discoveries was made during an investigation of a cistern constructed in Venetian times and rebuilt by the Turks. Two inscriptions, one whole and the other fragmentary, were immured into the central pillar supporting the roof of the cistern. Three inscriptions were preserved on one of these two blocks. On the one ofthe Latin text, Scoder is mentioned as a Roman colony. In late Roman times Scoder was the capital of the Praevalis province. The wall, excavated by us, surrounding the lower town dates to this period. One of the mysteries of Scoder was a bulwark below the north wall of the fortifications The present investigations have identified the wall as a defensive structure raised by the Venetians during the Turkish siege of 1478/1479. Three other interesting discoveries concern the $17^{\text {th }}$ and $18^{\text {th }}$ centuries. A set of almost 30 glass aryballoi were found in the ruins of one of the Turkish houses. Another hoard, found this time in a water sewer which is always interesting to the archaeologist, contained a small bag of silver coins struck in Dubrovnik in the early $17^{\text {th }}$ century as well as a series of majolica vessels covered with a colored glaze and even some imported Chinese porcelain. An apothecary's shop in the lower town yielded the remains of scales, vessels and a well preserved small tin pyxis The inscription on its cover identifies its content as "thyriaca”, an antidote known to English apothecaries as Venice treacle.

\section{Bibliography}

Cabanes P., Les Illyriens de Bardylis à Genthios (IV ${ }^{\mathrm{e}}-\mathrm{II}^{\mathrm{e}}$ s. av. J.C.), Paris 1988.

Ceka N., The Illyrians to the Albanians, Tirana 2005.

Dyczek P., Kolendo J., Łajtar A., Płóciennik T., Rzepkowski K., Iliryjski bóg Medurus i mury Risinium w świetle inskrypcji metrycznej z Lambaesis (CIL VIII 2581; F. Buecheler, Carmina Latina epigraphica 1527), Novensia 21, 2010(2012), pp. 79-133 .

Dyczek P., Kolendo J., Łajtar A., Płociennik T., Rzepkowski K., Une inscription métrique de Lambaesis (CIL, VIII, 2581; F. Buechler, Carmina Latina epigraphica. 1527) et la statue du dieu illyrien Médaure, Antiquités africaines, 50, 2014, pp. 73-84.

Dyczek P., Lar populi sancte Medaure...(CIL III, 2581=ILS 4881), Anodos. Studies of the Ancient World 6-6 (2006-2007) 2008, pp. 155-163.

Dyczek P., Rhizon in der Zeit des Königs Ballaios, Kontaktzone Balkan, Beiträge des internationalen Kolloquiums Die Donau-Balkan-Region als Kontaktzone zwischen OstWest und Nord-Süd vom 16.-18. Mai 2012 in Frankfurt a. M., Kolloquien zur Vor- und Frügeschichte, 20, 2015, pp. 107-116.

Dyczek P., Rhizon, 2001-2003. Preliminary Report on the Excavations of the Center for Archaeological Research - Novae, Warsaw University, Archeologia 55, 2004 (2005), pp. 101-118.

Dyczek P., Rhizon, 2004-2007. Preliminary Report on the Excavations of the Center for Research on the Antiquity of Southeastern Europe, Warsaw University, Archeologia 58, 2007(2008), pp. 121-139. 
Dyczek P., Rhizon, 2008-2012. Preliminary Report on the Excavations of the Center for Research on the Antiquity of Southeastern Europe, University of Warsaw, Archeologia 62-63, 2011-1012, 2014, pp. 91-109.

Dyczek P., Shpuza S., Three years of Albanian-Polish excavations in Shkodra, [in:] L. Përzhita, I. Gjipali, G. Hoxha, B. Muka (eds.), Proceedings of the International Congress of Albanian Archaeological Studies. 65 $5^{\text {th }}$ Anniversary of Albanian Archaeology (21-22 November, Tirana 2013), Botimet Albanologjike, Tiranë 2014, pp. 387-398.

Dyczek P., Shpuza S., Shkdër. Gërmimet arkeologjike të viteve 2013-2014, Iliria 38, 2015, pp. 279-292.

Dyczek P., Shpuza S., Tre vjet gërmime shqiptar o-polake në Shkodër, Iliria 38, 2015, pp. 9-22.

Fistani F., Vendbanimiifortifikuar Vendbanimiifortifikuarilir i Kratulit, Iliria 1983, 1, pp. 109-117 .

Garašanian M., Moenia Aecia Starinar 17, 1966, pp. 27-36.

Hoxha G., Gjurmë të periudhës së bronzit të hershëm në kalanë e Shkodrës, Iliria 1987, 1, pp. 71-81.

Hoxha G., Kalaja e Mosketi, Candavia 1, 2004, pp. 245-250.

Islami S., Qyteti ilir në Zgërdhesh, Iliria 2, pp. 195-213.

Lahi B., Kalaja e Ganjollës, Iliria 1992, 1-2, pp. 201-218.

Łajtar A., Shpuza S., Żelazowski J., Nowe inskrypcje z antycznej Szkodry (Albania) znalezione podczas polsko-albańskich badań archeologicznych, Novensia 25, 2014, pp. 127-143 .

Łajtar A., Żelazowski J., Le nuove iscrizioni provenienti da Scodra (Albania) e il nuovo v(ir) e(gregius) ducenarius*, ZPE 192 (2014), pp. 273-283.

Lisičar P., Legenda o Kadmu, Živa antika 3, 1953, pp. 245-260.

Mijović P., Kovačević M., Gradovi i utverđenja u Crnoj Gori, Ulcinj 1975.

Nielsen I., Hellenistic Palaces, Studies In Hellenistic Civilisation, eds. P. Bilde, T. EngberPedersen, L. Hannelstad, J. Zahle, V, 1999.

Pająkowski W., Ilirowie, Poznań 1981.

Prodeva N., Enchéléens-Dassarétes-Illyriens. Sources littéraires, épigraphique et archéologiques. L'Illyrie méridionale et l'Épire dans l'Antiquité. Actes du 2e Colloque International de Clermont-Ferrand, 25-27 octobre 1990, Paris 1993, pp. 195-199.

Šašel Kos M., Mythological stories concerning Illyria ant its name, [in:] L'Illyria méridionale at l'Épire dans l'Antiquité, eds P. Cabanes, J.-L. Lamboley, Paris 2004, pp. 500-501.

Šašel Kos M., Cadmus and Harmonia in Illyria, Arheološki vestnik 44, 1993, pp. 113-136.

Shpuza S., Iron age fortifications and the origin of the city in the territory of Scoder, Novensia 25, 2014, pp. 105-126. 
